\title{
$\mathrm{Obituary.}$
}

\section{Rev. H. J. BIDDER.}

$T H$ E death of Henry Jardin Bidder, fellow of St. John's College, Oxford, which took place on October ig at his house in Oxford, deprives his College and University of a wise counsellor and the world of a rare and commanding personality.

Mr. Bidder was born in 1847 , and after his schooldays at Harrow, spent the whole of his long life in, or in the neighbourhood of, Oxford. He was elected to a fellowship at St. John's in 1873 , and having taken Orders, found ample scope for his abounding energy in the service of the Church and in acting as lecturer and tutor and subsequently as Bursar of his College. The post of Bursar he held for twenty-one years, and during that period Mr. Bidder administered the financial affairs of his College with such judgment and ability that when he resigned the office St. John's had become one of the most flourishing colleges in the University.

A man of wide sympathies, Mr. Bidder espoused with enthusiasm the cause of agriculture and forestry in "the University. He took a leading part in effecting the re-endowment of the Sibthorpian professorship of rural economy and in the establishment of a professorship of forestry. Nor will it be ungracious to state that the weight of his influence counted heavily in determining his college to give generous assistance to these departments of the University, in assisting in the provision of buildings, and in putting Bayley Wood at the disposal of the School of Forestry as a training ground for foresters. Mr. Bidder served for many years on the University Forestry Delegacy and was also a most valued Curator of the Oxford Botanic Garden.

Of the many services which Mr. Bidder rendered to the world none is more conspicuous nor more widely appreciated than that of making the garden of St. John's College the most beautiful in the University and among the most beautiful in the world. To the lot of few men has it fallen to give pleasure to so many as did he by his labours in making " his" garden more perfect year by year. Those who shared his love of gardening were sure of a warm welcome to St. John's and a warm place in his heart, and there are many who count among the happiest hours of their life those spent with Mr. Bidder in St. John's garden. They were never sent empty away, but received the gifts of his large-hearted friendship and of any, even of his most precious, plants which they desired. The rock garden, designed with consummate skill and tended with meticulous care, was perhaps the achievement of which Mr. Bidder was most proud : and justly, for in it Alpine plants, even the most difficult, found congenial place, and flourished so that they made St. John's rock garden in springtime the most lovely corner of Oxford.

Tall and stalwart, authoritative, broad-minded, not always very patient, but of exquisite courtesy, Mr. Bidder was greatly beloved. He was humorous, too, with a spice of teasing malice which gave piquancy to his conversation and endeared him the more to his friends. His voice was beautiful, and there was a graciousness in his demeanour which made each time of meeting him a memorable occasion.

F. K.

\section{Dr. William Crooke.}

IT is with great regret that we record the death of Dr. William Crooke, the widely-known authority on Indian ethnology, which occurred on October 25 after an operation.

William Crooke was born in I848, and after taking his degree at Dublin University, entered the Indian Civil Service (Bengal) in $\mathrm{r} 87 \mathrm{x}$. While engaged in official duties as magistrate and collector in the United Provinces of Agra and Oudh, he took up the study of ethnology. As a result, in 1896 he published "Popular Religion and Folklore of Northern India," and "The Tribes and Castes of the North-Western Provinces and Oudh." The latter was undoubtedly his greatest work. It naturally owed much to his predecessors, such as Risley Dalton, Tòd, and Malcolm ; but it differed from any previous account in supplying a more detailed description of the manners, religions, marriage customs, and institutions of the people. Its most valuable part was the record of Crooke's own observations, made in the course of a long service at Mirzapore, on the Dravidian peoples, whose culture was then rapidly disappearing before Brahmanical propaganda.

On his retirement from the Civil Service, Crooke was for a time honorary secretary of the Royal Anthropological Institute ; but he finally settled at Cheltenham and devoted himself to the study of folklore and Indian ethnology. These studies bore fruit in a number of contributions to the proceedings of learned societies and in other publications. In addition to the two books mentioned above he published: "An Indian Glossary," I903; "Things Indian," 1906 ; and "The Peoples of Northern India," I907. He also contributed a large number of articles to Hastings' " Encyclopædia of Religion and Ethics." For many years he was a constant contributor of paragraphs on anthropological subjects to NATURE, and his last contributions were received only a few days before he entered the nursing home where he died.

Crooke's intimate acquaintance with folklore and primitive custom, as well as his wide knowledge of Indian archæology and history, and his explorations in the byways of the literature on India, rendered him an ideal editor. In this capacity he produced Fryer's "New Account of East India and Persia" (Hakluyt Society, r909); Tod's "Annals and Antiquities of Rajasthan," r920 ; and Herklot's "Islam in India," I92I. In each case his work was highly praised by the most competent critics.

In I9I0, Crooke was president of the Anthropological Section of the British Association at the Sheffield meeting, and in $\mathrm{rgr} \mathrm{r}-\mathrm{r} 2$ he was president of the Folklore Society. In rgrg the University of Oxford conferred upon him the honorary degree of D.Sc., and in I920 his own University of Dublin honoured him with the degree of Litt.D. He had recently been elected a fellow of the British Academy.

WE regret to announce the following deaths :

Mr. Charles Burckhalter, astronomer and meteorologist, director of the Chabot Observatory since 1885 , on September 20, aged seventy-four.

Prof. H. B. Rathke, formerly honorary professor of chemistry at Marburg University, aged eighty-four.

NO. 28 I 8 , vOL. I I 2 ] 